\title{
Speciation and Sources of Toxic Metals in Sediments of Lake Chapala, Mexico
}

\author{
Juan Luis Trujillo-Cárdenas, ${ }^{a}$ Nereida P. Saucedo-Torres, ${ }^{a}$ Pedro Faustino Zárate del Valle, ${ }^{a}$ Nely Ríos- \\ Donato, ${ }^{a}$ Eduardo Mendizábal, ${ }^{a}$ Sergio Gómez-Salazar ${ }^{b}$
}

\begin{abstract}
Departamentos de ${ }^{a}$ Química e ${ }^{b}$ Ingeniería Química, Universidad de Guadalajara. Centro Universitario de Ciencias Exactas e Ingenierías, Blvd. M. García Barragán \# 1451, Guadalajara, Jalisco, México 44430, Tel. +52 3336503401 , Fax: +52 333619 7316,sergio.gomez@cucei.udg.mx
\end{abstract}

Received July 22, 2009; accepted March 12, 2010

\begin{abstract}
Heavy metals chemical speciation in Lake Chapala sediments was studied using sequential extraction to assess the mobility of potentially biotoxic metals and to elucidate their sources. Lake water quality was also studied. Results show $\mathrm{Cd}, \mathrm{Pb}, \mathrm{Cr}$ present in exchangeable and carbonate fractions indicating anthropogenic origin. An ecologic history indicates anthropogenic sources of $\mathrm{Cd}, \mathrm{Pb}$, Cr during 1960-2006. Risk Assessment Code indicates very high risk of pollution for water column due to high potential detachment of heavy metals.
\end{abstract}

Key words: sediments; toxic metals; speciation; lake pollution.

\section{Introduction}

Metals enter the aquatic environment from a variety of sources, including those naturally occurring through biogeochemical cycles [1] and those added through anthropogenic sources, namely from industrial and domestic effluents, urban, storm water runoff, landfill leachate, and atmospheric sources [2]. The migration behavior and bioavailability of metals is controlled by the way in which metal ions are distributed between the aqueous and particulate phases. As a result, sediments act not only as transport media of contaminants, but also as potential secondary sources of contamination of an aquatic system [3]. Changes in environmental conditions (e.g., variations in $\mathrm{pH}$, redox potential, metal concentrations in solution, and complexation) may cause metals to be remobilized from sediments, thus posing an environmental risk [4].

To assess the potential pollution effects of metal-bearing sediments to biota (e.g., bioavailability and toxicity), the sole criterion of total metal concentration can not provide data about the extent of pollution [5] due to the assumption that all the species of a particular metal have equal impact on the ecosystem [6]. As a result, other analytical methods must be implemented, such as metal fractionation [7]. The advantages of sequential chemical metal speciation over total metal extraction include: 1) assessment of the source of a particular metal (i.e., natural or anthropogenic), 2) determination of the relative toxicities to aquatic biota, and 3) a better understating of metal-sediment interactions [8]. On the other hand, since the mobility of a metal and its bioavailability also depend on its speciation, considerable attention has been paid to this aspect in lacustrine systems. For example, Fityanos et al. [9]
Resumen. La especiación química de metales pesados en sedimentos del Lago de Chapala fue estudiada usando extracción secuencial para evaluar la movilidad de metales potencialmente biotóxicos y para determinar su origen. La calidad del agua del lago también fue estudiada. Los resultados muestran a $\mathrm{Cd}, \mathrm{Pb}, \mathrm{Cr}$ presentes en fracciones intercambiables y de carbonatos indican su origen antropogénico. Una historia ecológica indica fuentes antropogénicas de $\mathrm{Cd}, \mathrm{Pb}, \mathrm{Cr}$ durante 1960-2006. El Código de Evaluación de Riesgo indica riesgo muy alto de contaminación a la columna de agua debido al alto potencial de desprendimiento de estos metales.

Palabras clave: Sedimentos; metales tóxicos; especiación; contaminación del lago.

employed a five-step sequential metal extraction procedure to evaluate pollution by six metals $(\mathrm{Cd}, \mathrm{Cr}, \mathrm{Pb}, \mathrm{Mn}, \mathrm{Zn}$, and $\mathrm{Cu}$ ) of two lakes of Northern Greece, Volvi and Koronia. Their findings demonstrated that $\mathrm{Cd}, \mathrm{Cr}, \mathrm{Pb}$ and $\mathrm{Cu}$ were bound to oxidizable and residual fractions, and to a lesser extent, to carbonate fractions thus posing a low pollution risk to the lakes. In contrast, Dollar et al. [10] employed the sequential extraction scheme of Tessier et al. [6] to separate the portion of a metal bound to different geochemical groups at Indiana Dunes National Lakeshore. Their results showed a potential risk of pollution by the release of $\mathrm{Cd}, \mathrm{Pb}$, and $\mathrm{Cr}$ present in the exchangeable and carbonate fractions (attributed to anthropogenic sources). In the case of the Mexican Lerma-Chapala Watershed, previous studies using total metal concentrations demonstrated that suspended sediments acted as transport vectors of six metals $(\mathrm{Cd}, \mathrm{Cr}, \mathrm{Ni}, \mathrm{Cu}, \mathrm{Pb}, \mathrm{Zn})$ along the Lerma River, with Lake Chapala as the final destination of these pollutants [11]. However, these studies do not envisage the sources of pollution of those metals, thus limiting the extent of contamination assessment that would be helpful in proposing more effective pollution control procedures.

In view of the lack of studies that evaluate the heavy metal pollution risks from sediments to water from Lake Chapala, the main objective of the present study was to investigate - using a five-step sequential extraction procedure - the geochemical groups the different trace metals belong to $(\mathrm{Cr}, \mathrm{Pb}, \mathrm{Cu}, \mathrm{Cd}, \mathrm{Ni}, \mathrm{Zn})$. The procedure was used for the study of the sediments from two sites of this lake and the potential pollution risk they pose to the water column. The source of metals was determined at a point in the depocenter of the lake (Site 8, Figure 4), and at a point near the 
intake site of the aqueduct that supplies water to the city of Guadalajara (Site 9, Figure 4). The depocenter of a basin is the area of maximum sediment deposition, i.e., the place where the sedimentary column reaches its thickest value and the sedimentary process is disturbed the least [12]. An ecologic history of $40+$ years was reconstructed for site 8 based upon sediment samples at a depth of $10 \mathrm{~cm}$.

\section{Results and discussion}

\section{Physicochemical parameters of waters from Lake Chapala}

The results of water quality measured through several physicochemical parameters of various sites of Lake Chapala are shown in Table 1. As a guideline for $\mathrm{pH}$ ranges, the World Health Organization (WHO) [13] sets an acceptable $\mathrm{pH}$ range of 6.5-8.5 for this type of freshwater bodies. The $\mathrm{pH}$ values obtained in this study are in the range of 7.79-8.82 indicating a slight alkalinity of the lake. Conductivity, which reveals the status of pollution by major inorganic ions and is taken as a measure of Total Dissolved Solids (TDS) and ionized species, shows values in the range of $659-837 \mu \mathrm{S} / \mathrm{cm}$ along the stations sampled. TDS values are in the range of $652-828 \mu \mathrm{g} / \mathrm{L}$, while total solids values (TS) vary from 1,333 to $5,333 \mathrm{mg} / \mathrm{L}$. TDS concentrations during the dry season suggest possible leaching from the basin through the Lerma River and erosion of

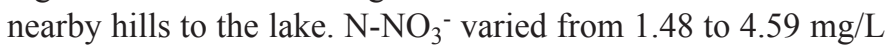
and phosphate concentrations $\left(\mathrm{P}_{-} \mathrm{PO}_{4}{ }^{3-}\right)$ varied from 13.77 to $23.53 \mathrm{mg} / \mathrm{L}$. Values of these nutrients are fairly high compared to values established by the United States Environmental Protection Agency Water Quality Criteria [14] which sets a maximum value of $0.025 \mathrm{mg} / \mathrm{L}$ of phosphates within a lake or reservoir. Nitrate and phosphate values of this study are higher compared to those reported by De Anda and Shear for the same lake [15]. High nitrate and phosphate concentrations can be attributed to the widespread use of phosphate-rich fertilizers and detergents along the lake's shoreline and along parts of the Lerma River close to the lake used for agricultural and livestock activities. Chemical Oxygen Demand (COD) varied from 16 to $43 \mathrm{mg} / \mathrm{L}$ and dissolved oxygen concentrations (DO) ranged from 7.18 to $9.88 \mathrm{mg} / \mathrm{L}$. These values are indicative of a good oxygen saturation level. In fact, east-west and west-east wind velocities can reach values above $9 \mathrm{~km} / \mathrm{h}$ and are responsible for maintaining water circulation, keeping waters under a good mixing regime [15-16]. $\mathrm{BOD}_{5}$ values for all sites comply with Mexican standards for waters to be used for human consumption after a purification treatment [17].

Distribution curves of total metal concentrations in the lake's water (including suspended matter) are shown in Figure 1. Cadmium concentrations $\left(7-9.6 \mu \mathrm{gL}^{-1}\right)$ decrease in the east to west direction of the lake with the highest concentrations observed at the Lerma River inlet. This trend suggests that $\mathrm{Cd}$ has been introduced into the lake through the Lerma River stream. Suspended sediment is known to be the main transport vector of $\mathrm{Cd}$ through the Lerma River [18]. The presence of this metal should be monitored since water from Lake Chapala is used for human consumption. In the cases of $\mathrm{Pb}$ and $\mathrm{Zn}$, their concentrations show an increasing trend from east to west, suggesting that a large portion of these metals is not added into the lake through the Lerma River stream, but by populations located along the lakeshore. The highest concentrations of $\mathrm{Zn}$ and $\mathrm{Pb}$ are observed at site $6(\mathrm{Zn}=35.6$, $\mathrm{Pb}=109.3$, in $\left.\mu \mathrm{g} \mathrm{L}^{-1}\right)$ and site $9(\mathrm{Zn}=41.1, \mathrm{~Pb}=174.4$, in $\left.\mu \mathrm{gL}^{-1}\right)$. In the case of site 6 , these levels can be attributed to untreated municipal discharges of the mid size city of Tizapan

Table 1. Physicochemical parameters of waters from nine sites of Lake Chapala

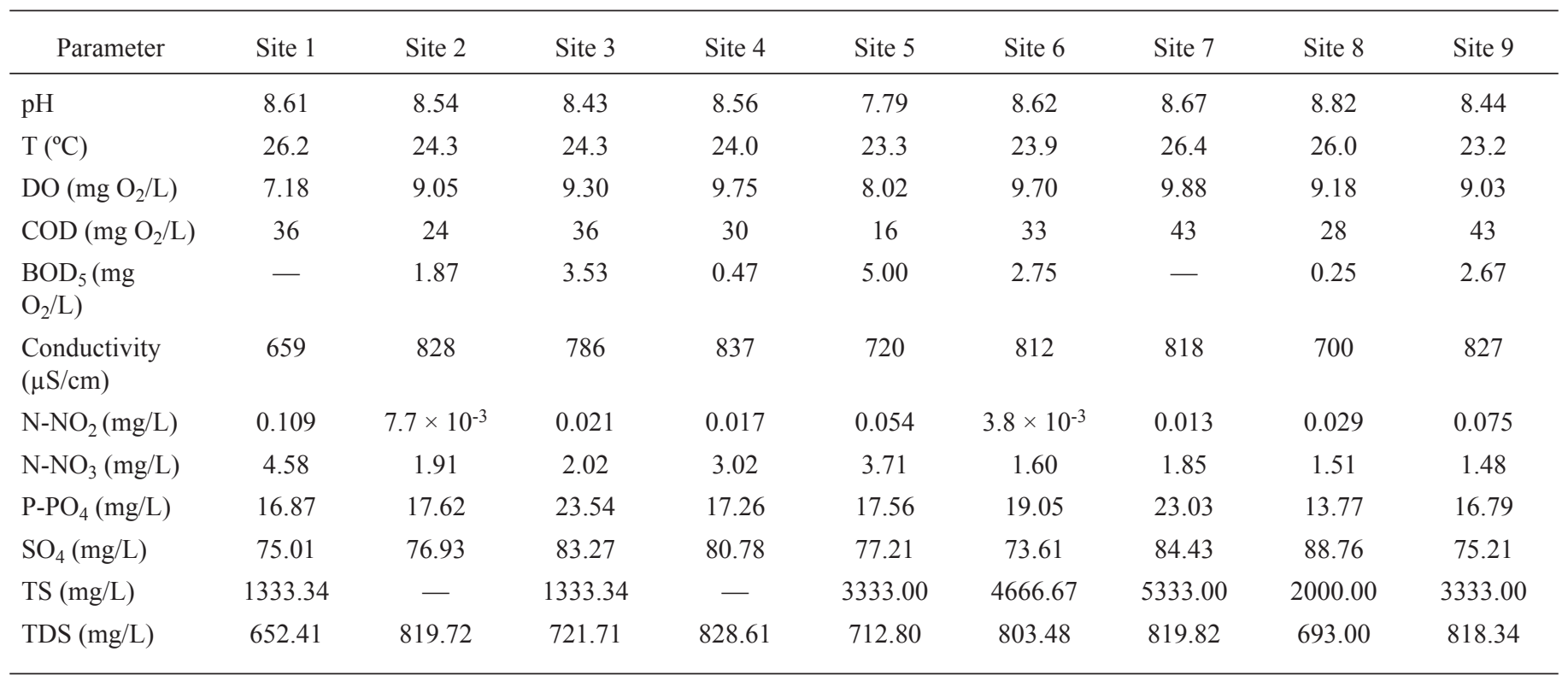




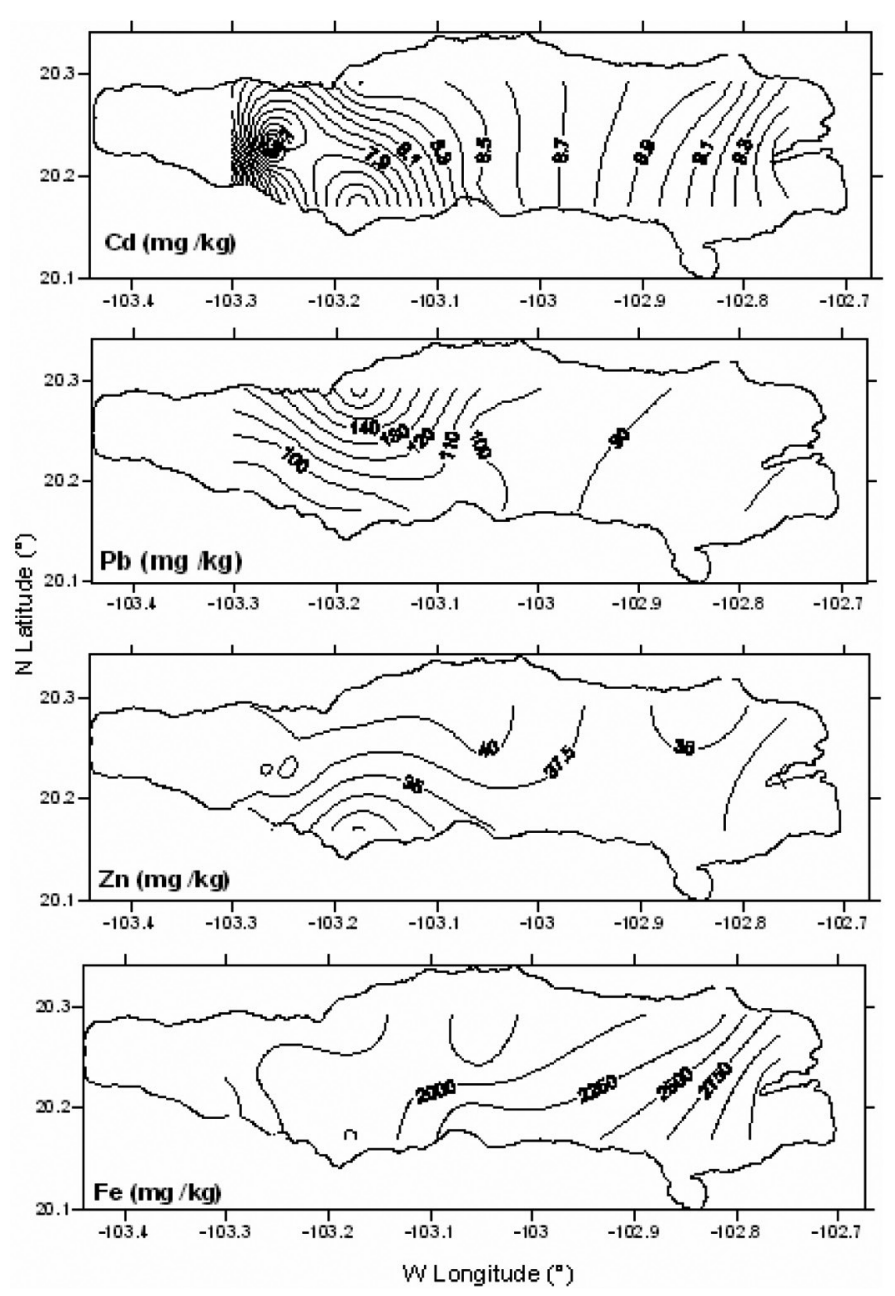

Fig. 1. Distribution curves of total metal concentrations $(\mu \mathrm{g} / \mathrm{L})$ in waters at nine sites of Lake Chapala. Instrument detection limits $(\mu \mathrm{g} /$ $\mathrm{L}): \mathrm{Cd}=3 ; \mathrm{Pb}=50 ; \mathrm{Cr}=20 ; \mathrm{Zn}=5 ; \mathrm{Ni}=20 ; \mathrm{Cu}=10$.

(pop. $\sim 20,000$ ) and to runoffs. In the case of site 9, the presence of $\mathrm{Pb}$ and $\mathrm{Zn}$ can be due to untreated wastewaters from galvanizing plants (located in the village of Chapala). In the case of $\mathrm{Fe}$, the high concentrations observed can be attributed to sediment resuspension due to wind action in this shallow lake [19]. $\mathrm{Cr}$ and $\mathrm{Cu}$ are below the detection limit of the instrument at all sites.

\section{Physicochemical characteristics of Lake Chapala sediments}

The physicochemical characteristics of Lake Chapala sediments from sites 8 and 9 are shown in Table 2. Sediment $\mathrm{pH}$ was 8.22 (site 8 ) and 8.29 (site 9), indicating their slightly alkaline nature. The low organic matter content (site 8: 0.61 $\%$; site 9: $0.51 \%$ ) and the presence of carbonates (site 8 : $0.11 \%$; site 9: $0.22 \%$ ) in sediments of these sites can explain the relatively low amounts of metals bound to the organic matter fraction and the predominance of some metals present in
Table 2. Sediment characteristics of two sites of Lake Chapala

\begin{tabular}{cccccc}
\hline Site & $\begin{array}{c}\text { Sample } \\
\text { source }\end{array}$ & $\mathrm{pH}$ & $\begin{array}{c}\text { \% Organic } \\
\text { matter }\end{array}$ & $\begin{array}{c}\text { \% Carbonates } \\
(\text { as C }\end{array}$ inorg $)$ & $\begin{array}{c}\zeta \text {-potential, } \\
\mathrm{mV}\end{array}$ \\
\hline 8 & $\begin{array}{c}\text { top 30 } \\
\text { cm solid } \\
\text { phase } \\
\text { water- } \\
9\end{array}$ & 8.22 & 0.60 & 0.11 & -26.80 \\
& $\begin{array}{c}\text { sediment } \\
\text { interface }\end{array}$ & 8.29 & 0.51 & 0.22 & -16.92 \\
\hline
\end{tabular}

the carbonate fraction (e.g. $\mathrm{Cd}, \mathrm{Pb}$, and $\mathrm{Cr}$ ), as will be shown in the fractionation studies section. The carbonate contents at both sites are in agreement with literature reports which indicate that terrigenous particles are the major component of sediments with ca. $2-5 \%$ wt. calcite $\left(0.20-0.6 \mathrm{~g} \mathrm{C}_{\text {inorg }}\right)$ [20].

$\zeta$-potential values are -26.8 and $-16.9 \mathrm{mV}$ for sites 8 and 9 , respectively (Table 2). These values are characteristic of clay minerals and, to a lesser extent, of calcites which carry a net negative surface charge derived from isomorphic substitutions in the lattice [21]. Negative $\zeta$-potential of mineral particles in natural environments has been attributed to the adsorption of organic matter. Acting as a coating, organic matter renders the surface charge of particles uniformly negative regardless of their composition and structure. Even though literature data on $\zeta$-potential of organic substances is scarce, there is considerable information on the $\zeta$-potential of particles influenced by organic matter that clearly show the negative nature of the $æ$ potential formed after organic matter adsorption [22-24].

\section{Total metal concentrations in Lake Chapala sediments}

The total metal concentrations in sediments of two sites of Lake Chapala are shown in Table 3 along with the Average Abundance of Metal in Basaltic Rocks (AAMBR) [25], LEL and SEL values. LEL is the Lowest Effect Level; the majority of benthic organisms can tolerate this level whose value is obtained by using field data on the co-occurrence of sediment concentrations and benthic species [26-27]. SEL stands for Severe Effect Level and it represents contaminant concentrations in sediments that could potentially eliminate most of the benthic organisms [27]. AAMBR, LEL and SEL values are taken here as reference points to assess the level of contamination of Lake Chapala sediments. $\mathrm{Cd}$ and $\mathrm{Pb}$ concentrations exceed AAMBR, LEL and SEL at both sites, with the highest value at site 8 . Due to the alkaline nature of water in the lake, metals such as $\mathrm{Pb}$, and to a lesser extent $\mathrm{Cd}$, can be present as precipitates in the sediments and settled as carbonates, oxides and hydroxide-bearing sediments; elevated metal concentrations indicate higher exposure risks to the benthic biota of the lake. The rest of metals show the following trend at both sites: $\mathrm{Cr}<\mathrm{SEL}$, AAMBR, LEL; LEL $<\mathrm{Zn}<\mathrm{SEL}$; AAMBR, SEL $>$ Mn $>$ LEL at site 8; Mn > AAMBR, SEL, LEL at site 9. 
Table 3. Total metal concentrations $(\mathrm{mg} / \mathrm{kg}$ ) in sediments of two sites of Lake Chapala and their comparison with AAMBR, LEL and SEL standard values.

\begin{tabular}{cccccc}
\hline Metal & Site 8 & Site 9 & $\begin{array}{c}\text { Average Abundance } \\
\text { of Metal in Basaltic } \\
\text { Rocks (AAMBR)* }\end{array}$ & LEL & SEL \\
\hline $\mathrm{Cd}$ & 14.9 & 15.9 & 0.02 & 0.6 & 10 \\
$\mathrm{~Pb}$ & 268.8 & 181.5 & 5 & 31 & 250 \\
$\mathrm{Mn}$ & 961.5 & 1562.5 & 1500 & 460 & 1100 \\
$\mathrm{Cr}$ & 44.7 & 42.1 & 200.0 & 26 & 110 \\
$\mathrm{Zn}$ & 140.0 & 243.6 & 100.0 & 120 & 820 \\
$\mathrm{Ni}$ & 60.2 & 62.0 & 150.0 & 16 & 75 \\
$\mathrm{Cu}$ & 38.2 & 40.5 & 100.0 & 16 & 110 \\
$\mathrm{Fe}$ & 23022.0 & 21650.2 & 8600 & N.A. & N.A. \\
\hline
\end{tabular}

*from ref [37]; N.A. = Not Available

\section{Fractionation studies}

Potentially toxic metals were found in the five extracts of the sequential procedure. Singh et al. [5] and Jain [8] suggested that a large part of metals introduced by human activity were present in the exchangeable fraction and the fraction dissolved with acetic acid (carbonates). It can be assumed that the portion of metals that is the most liable to be released from a sediment corresponds to the portion extracted during the first two steps. Metals bound to the easily reducible phase (Fe/Mn oxides) and to organic matter and sulfides may be better held by a scavenging effect (i.e., this fraction acts as a sink of metals). Metals in the residual fraction, strongly bound to solid matter, originate mainly from natural sources [28]. The speciation patterns of different metals in Lake Chapala sediments from sites 8 and 9 are shown in Figure 2. Cd profiles at the two sites feature significant portions bound to the exchangeable and carbonate fractions; a small portion is present in the organic matter fraction at site 9, whereas it is absent at site 8 in this fraction; the rest of $\mathrm{Cd}$ is present in the residual fraction. $\mathrm{Pb}$ fractionation at site 8 shows a major portion associated to both organic matter and exchangeable fractions, whereas $\mathrm{Pb}$ in the exchangeable fraction is predominant at site 9. Cr profiles at both sites show major portions bound to the residual fraction, followed by exchangeable, $\mathrm{Fe} / \mathrm{Mn}$ oxides, and carbonates. Zn distribution at both sites shows significant amounts bound to the residual fraction. $\mathrm{Ni}$ at both sites is mostly bound to the residual fraction and a moderate portion bound to the exchangeable and carbonates fractions. The $\mathrm{Cu}$ profile at both sites shows major portions bound to the residual fraction. It is evident from these results that major portions of the metals studied here are bound in different forms with different strengths. In summary, sites 8 and 9 show significant amounts of $\mathrm{Cd}, \mathrm{Pb}$ and $\mathrm{Cr}$ that were leached out from the sediment during the first two steps (exchangeable and carbonate fractions). It is likely that these
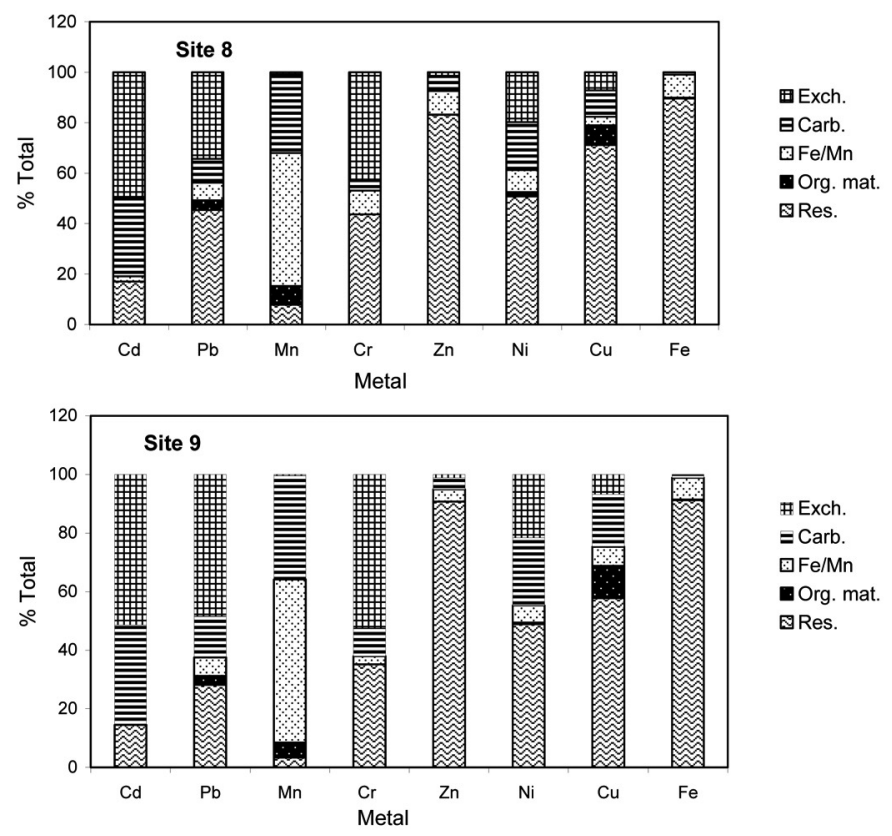

Fig. 2. Speciation of heavy metals in sediments of two sites from Lake Chapala. Exch.= exchangeables; Carb.= carbonates; $\mathrm{Fe} / \mathrm{Mn}=$ Fe/Mn oxides; Org. mat.= Organic Matter; Res.= Residuals.

metals have been introduced into the lake mostly by anthropogenic activities.

The reactivity of sediments was evaluated by applying the criterion of the Risk Assessment Code [29]. This criterion (shown in Table 4) considers that when less than $1 \%$ of the total metal content is bound to the exchangeable and carbonate fractions, i.e., liable to be released from the sediment, the latter will be considered safe for the environment; when more than $50 \%$ of the total metal content can be released from exchangeable and carbonate fractions, the sediment will be considered of very high risk; the rest of the classification includes low risk (1-10\%), medium risk (11-30\%) and high risk (31-50\%). This code, applied to sites 8 and 9 , reveals that about $39-63 \%$ of the lead, $86-89 \%$ of cadmium and $47-62 \%$ of $\mathrm{Cr}$ was present in the exchangeable and carbonate fractions thus posing a very high risk of pollution at these two sites. $\mathrm{Cu}, \mathrm{Ni}$, and $\mathrm{Zn}$ were mostly present in the $\mathrm{Fe} / \mathrm{Mn}$ oxides, organic matter and residual fractions thus posing a low risk of pollution at both sites.

Table 4. Criteria of the Risk Assessment Code [40].

\begin{tabular}{cc}
\hline Risk Assessment Code (RAC) & Criteria (\%) \\
\hline No risk & $<1$ \\
Low risk & $1-10$ \\
Medium risk & $11-30$ \\
High risk & $31-50$ \\
Very high risk & $>50$ \\
\hline
\end{tabular}


The measurements for the stratigraphic control of Lake Chapala were based on: a) grain-size analyses on 13 gravity core samples, and b) mass magnetic susceptibility vertical profiles $\left(\chi\right.$, in $\left.\mathrm{m}^{3} \mathrm{~kg}^{-1}\right)$ developed on five gravity core samples distributed throughout the lake at different elevations above sea level (identified as CHP 75, CHP 40, CHP 30, CHP 71 and CHP 55) [30]. A generalized east-west profile from Lake Chapala with the projected separation distances between each point from which the cores were taken, is shown in Figure 3 . The results of these measurements indicate that shallow sediments are silty and dark with a granulometric median of 5 to $20 \mu \mathrm{m}$ in diameter. There are some levels thinner than 2 $\mathrm{mm}$ containing coarser grains $(80-150 \mu \mathrm{m})$ of volcanic origin which have been attributed to both the presence of ash fall and high titano-magnetite concentrations intercalated in the sedimentary column [31]. On the other hand, the continuous line joining all graphs shown in Figure 3, identifies the coarser grain level as lithologic marker horizon due to their high mass magnetic susceptibility $\left(\chi>2000 \times 10^{-9} \mathrm{~m}^{3} \mathrm{~kg}^{-1}\right)$ and their general distribution throughout the lake.

Sedimentation rates in lakes (SR) are generally rather variable in the different geographies, and Lake Chapala is not an exception. SR's at lake Chapala were deduced by Fernex et al. [31] based on ${ }^{210} \mathrm{~Pb},{ }^{137} \mathrm{Cs}$ and ${ }^{240} \mathrm{Pu}$ radiometric methods applied on gravity core samples distributed throughout the lake. Their results showed SR variations as follows: in the western part of the lake, SR $\leq 2 \mathrm{~mm}$ year $^{-1}$; in both the depocenter and the eastern area, $\mathrm{SR} \geq 2.5 \mathrm{~mm}$ year $^{-1}$; and near the Rio Lerma inlet, SR $>3.5 \mathrm{~mm}$ year $^{-1}$. Therefore, by considering an approximate SR value of $2.5 \mathrm{~mm}^{\text {year }}{ }^{-1}$ (corresponding to the depocenter), a depth of $-10 \mathrm{~cm}$ of sediments from site 8 is correlated to represent a history of $\sim 40$ years between 1960-2000. It is then possible to predict the source of metals present in the sediments of the lake during a given time period. For example, in the case of lead, a total of $268.8 \mathrm{mg} \mathrm{kg}^{-1}$ was found in this study from which $\sim 43 \%$ was present in both

WEST

EAST

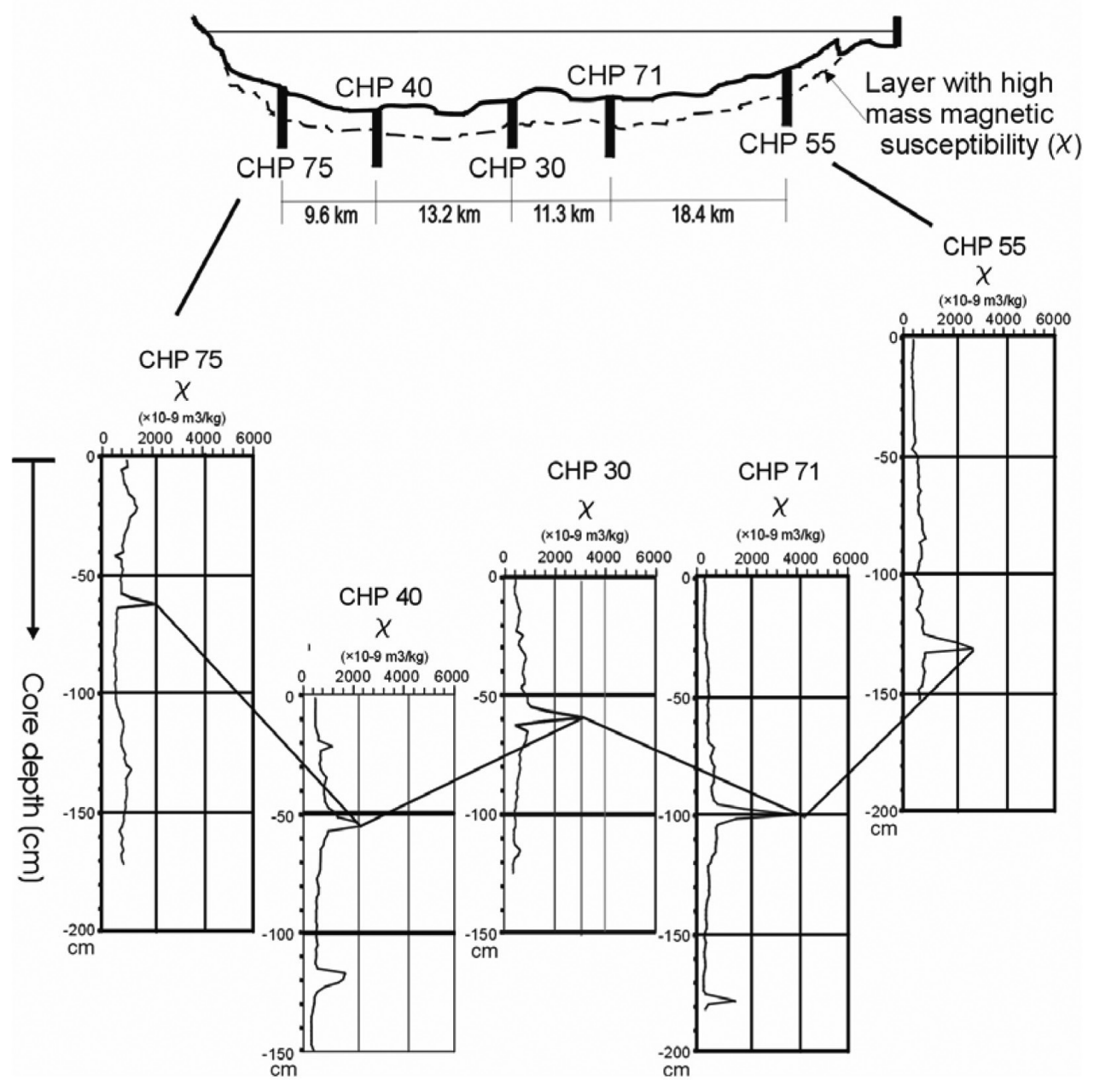

Fig. 3. Schematic of East-West longitudinal profiles of core projections (CHP 75, 40, 30, 71, and 55) of Lake Chapala depicting the location of the sandy layer thickness along with the mass magnetic susceptibility readings at different core depths. 
exchangeable and carbonate fractions. This means that 115.6 $\mathrm{mg} \mathrm{kg}^{-1}$ of this metal were introduced at site 8 mostly from anthropogenic sources from the mid 1960's through the first quarter of 2006. Following the same rationale, in the cases of chromium and cadmium, $20.9 \mathrm{mg} \mathrm{Cr} \mathrm{kg}^{-1}(46.7 \%=$ exch + carb; total $\left.44.7 \mathrm{mg} \mathrm{kg}^{-1}\right)$ and $12.3 \mathrm{mg} \mathrm{Cd} \mathrm{kg}^{-1}(82 \%=$ exch + carb; total $14.98 \mathrm{mg} \mathrm{kg}^{-1}$ ) were introduced into the lake at site 8 from anthropogenic activities during the same time period. $\mathrm{Cu}, \mathrm{Ni}$ and $\mathrm{Zn}$ fractionation results indicate chiefly natural sources of these metals. In the case of site 9, an ecologic history (as that obtained for site 8) cannot be determined since the samples at this site were taken from the water-sediment interface and not from the sedimentary column. However, metal speciation permits us to ascertain the source of a given metal in samples from this site, as discussed in the previous paragraph. Metal analyses of sites 8 and 9 suggest that pollution by $\mathrm{Pb}, \mathrm{Cd}$ and $\mathrm{Cr}$ from anthropogenic sources continues and that more strict measures should be taken to minimize this problem.

\section{Conclusions}

The analyzed physicochemical parameters of waters from Lake Chapala are within international values (WHO and USEPA). The presence of $\mathrm{Cd}$ in lake waters suggests the need of careful monitoring of the water supplied to the city of Guadalajara dedicated to human consumption. Parameters such as phosphates and nitrates exceed the corresponding limits set by WHO and USEPA. High concentrations of these nutrients were attributed to the widespread use of phosphate-rich fertilizers and detergents on pieces of land along the lake shoreline and in some parts of the Lerma River close to the lake. æ-potential values of Lake Chapala sediments for sites 8 and 9 were characteristic of clay minerals and were attributed to the adsorption of organic matter. For the first time, sequential metal extraction techniques were applied to two sites of Lake Chapala sediments to determine the origin of metal contaminants. At site 8 , we can conclude that $\mathrm{Cd}, \mathrm{Cr}$, and $\mathrm{Pb}$ were introduced to the lake via anthropogenic activities from the mid 1960's through the first quarter of 2006. Cd was likely introduced into the lake mainly through Lerma River inputs, whereas $\mathrm{Pb}$ and $\mathrm{Cr}$ were introduced via municipal and industrial discharges of untreated wastewaters of cities located along the lakeshore. This is in part due to the fact that Mexican water regulations do not require tertiary treatments to eliminate these toxic metals. By applying the Pollution Assessment Risk Code at sites 8 and 9 , these sites show a very high contamination risk due to the presence of $\mathrm{Cd}, \mathrm{Cr}$ and $\mathrm{Pb}$ in the two more labile fractions of the sediments (i.e., exchangeable and carbonates). A study is in progress to determine more accurately (via transport models) metal pollution point sources that would help to propose pollution control policies with the final objective of reducing the presence of toxic metals in the lake. Finally, metal concentration data in waters from Lake Chapala indicate the need for continuous monitoring of the levels of cadmium and lead in waters to be used for human consumption.

\section{Materials and methods}

\section{Study area}

The Lerma Chapala Watershed is located in the central part of Mexico and comprises the Lerma River and Lake Chapala as the final part (Figure 4). The watershed covers approximately $54,000 \mathrm{~km}^{2}$ of roughly basaltic lithology [20] and the Lerma River is $\sim 700 \mathrm{~km}$ long. The watershed receives $\sim 3 \%$ of the country's total rainfall, less than $1 \%$ of the runoff, and accounts for $\sim 13 \%$ of the total groundwater [11]. The lake is located in the western central part of the country between $20^{\circ} 07^{\prime}$ and $20^{\circ}$ $20^{\prime} \mathrm{N}$ and between $102^{\circ} 42^{\prime}$ and $103^{\circ} 25^{\prime} \mathrm{W}$ at about $1515 \mathrm{~m}$ above sea level; it covers a surface area of $\sim(80 \times 15) \mathrm{km}^{2}$, and its average depth varies between 4 and $7 \mathrm{~m}$, depending on: 1) the annual rainfall (affected by short-term fluctuations of 2 to 7 years due to El Niño Southern Oscillation (ENSO) and by changes of solar activity with periods of 11,22 and 45 years [32] and, 2) to a lesser extent, the amount of water extracted for human consumption. The lake is generally considered well mixed due to wind action and low depth which helps reducing stratification. As a result, the lake is oxidized (no eutrophication) at all depths [33]. Lake Chapala is of major importance to both ecologic systems and socioeconomic activities within the state of Jalisco. However, pollution of this water body by heavy metals has prompted concern since it provides $\sim 7.5 \mathrm{~m}^{3} / \mathrm{s}$ of water consumed by nearby Guadalajara [34]. The lake receives many contaminants coming from municipal, industrial, and agricultural activities that are discharged by cities located along the Lerma River [18]. For example, reports by Hansen and van Afferden [26] indicate that the city of León contributed with $\sim 48 \%$ of the lead to the Lerma River. At the same time, the cities of Celaya, La Barca, Salamanca, León and Querétaro (Figure 1) contributed all together with $\sim 42 \%$ of the cadmium. Unfortunately, a large portion of this metal ends up in Lake Chapala.

\section{Reagents and instruments}

All reagents were analytical grade and used without further treatment (Aldrich Chemical Co). Metal concentrations were analyzed with an atomic absorption spectrometer (AAS, Perkin Elmer Model AAnalyst 200). Certified standard metal ion solutions (Varian Instruments, Victoria, Australia) were used to obtain concentration versus absorbance calibration curves. Instrument detection limits $(\mu \mathrm{g} / \mathrm{L})$ were: $\mathrm{Cd}=3 ; \mathrm{Pb}=50 ; \mathrm{Cr}$ $=20 ; \mathrm{Zn}=5 ; \mathrm{Ni}=20 ; \mathrm{Cu}=10$. Blank solutions with the same composition as the target solution but without metal ions, were used as background for absorption corrections. If sample concentrations were out of the range of the calibration curve, they were diluted. All the solutions were prepared using deionized water with a resistivity of $18 \mathrm{M} \Omega$ (Barnstead filtration system). 


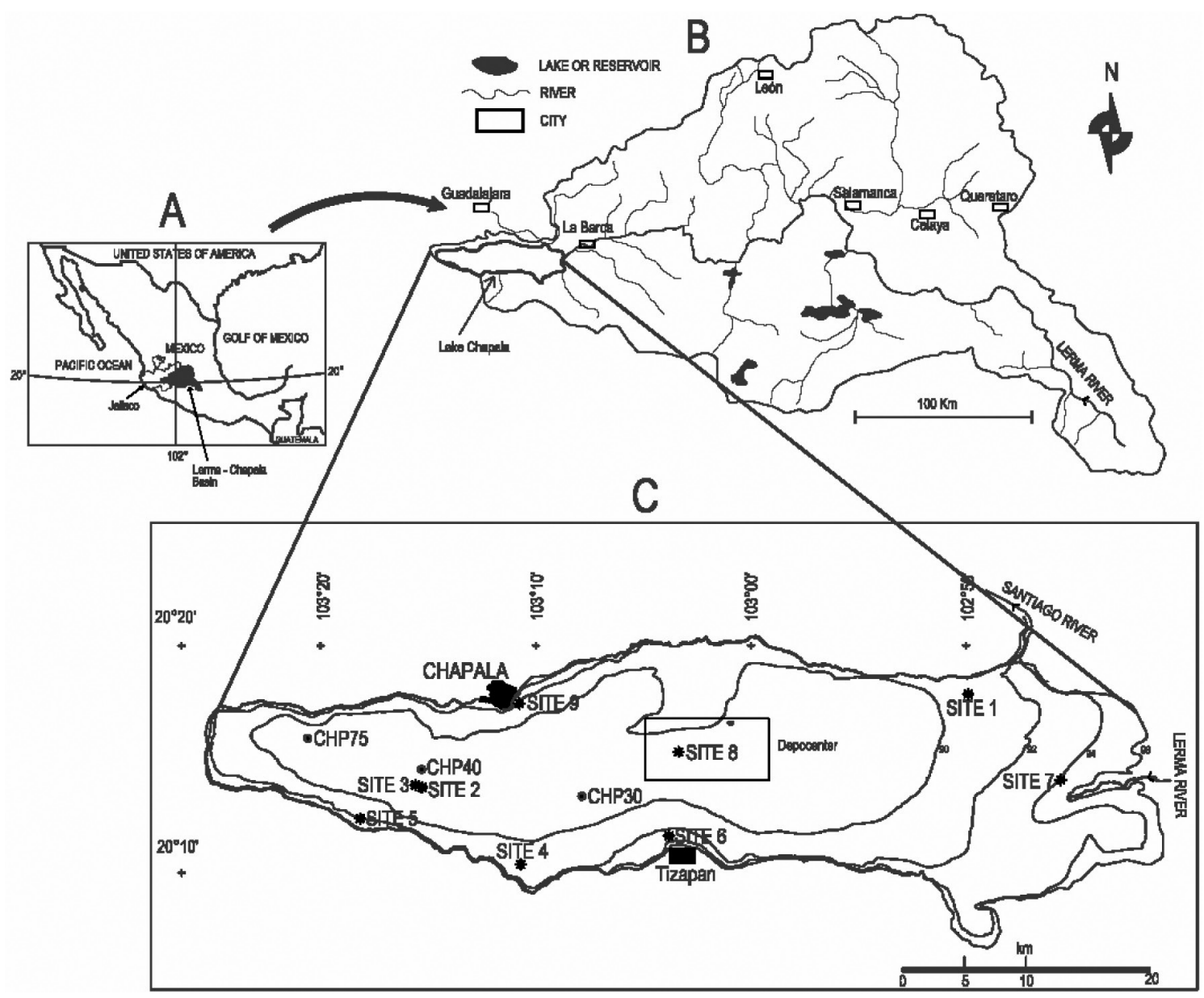

Fig. 4. Lerma-Chapala Watershed and location of sampling sites along Lake Chapala.

\section{Collection and analysis of water samples}

Water samples were collected during the 2006 dry season (March and April) from 9 different sites located along the lake (Figure 4), selected on the basis of their potential of pollution by heavy metals due to anthropogenic activities. Water samples were manually collected from approximately $30 \mathrm{~cm}$ beneath the water surface in polyethylene bottles (previously soaked in $\mathrm{HNO}_{3} 10 \% \mathrm{v} / \mathrm{v}$ for $24 \mathrm{~h}$ and rinsed several times with doubly distilled water). All samples were cooled at $4{ }^{\circ} \mathrm{C}$ and taken to the laboratory for further analysis. Dissolved oxygen (DO), temperature, and $\mathrm{pH}$ were determined in the field. The analyses of physicochemical parameters for water quality (shown in Table 1) and of total metal concentrations followed protocols established by the Mexican Standard [35] and APHA [36]. For total metal analysis (i.e., the sum of the concentrations of metals in both dissolved and suspended fractions), samples were acidified in the field with concentrated $\mathrm{HNO}_{3}(5 \mathrm{~mL}$ per liter of water) to lower the $\mathrm{pH}$ below 2; samples were then digested according to the APHA Method 3030K: Microwave-Assisted Digestion [36] in a programmable Microwave Oven Model Ethos Touch (Sorisole, Italy). Briefly, $45 \mathrm{~mL}$ of unfiltered lake water sample was placed into the digestion containers and 5
$\mathrm{mL}$ of conc. $\mathrm{HNO}_{3}$ was added. The oven was programmed to heat the samples in a first stage at $160 \pm 4{ }^{\circ} \mathrm{C}$ (545 Watts) for $10 \mathrm{~min}$ followed by a second heating stage at $165-170^{\circ} \mathrm{C}$ (344 Watts) for $10 \mathrm{~min}$. The containers were cooled down to room temperature and weighted. If the net weight percent of sample plus acid in the container decreased more than $10 \%$ after digestion, the sample was discarded and a new sample was digested. Blanks containing all the components except lake water sample were analyzed to determine background interferences.

\section{Sediment sampling}

Core sediment samples were taken from sites 8 and 9 (Figure 4). Site 8 was selected to evaluate the undisturbed natural conditions of the lake and site 9 due to its proximity to the intake site of the aqueduct. The depocenter was deduced from measurements of five magnetic signal profiles [37] and was found to cover an area of about $(5 \times 10) \mathrm{km}^{2}$ (see inset, Figure 4). Core sediments from site 8 were collected using a Benthos type gravity corer and immediately sealed to avoid contact with air; the first $10 \mathrm{~cm}$ were used for chemical fractionation analysis and to determine the ecologic history. Water-sediment 
interface samples from site 9 were taken with a cylindrical type nucleator device and the top $10 \mathrm{~cm}$ were used for chemical fractionation analysis. Samples from site 9 were placed in polyethylene bottles (previously soaked in $\mathrm{HNO}_{3} 10 \% \mathrm{v} / \mathrm{v}$ for $24 \mathrm{~h}$ and rinsed several times with doubly distilled water), immediately sealed to avoid contact with air, and transferred to the laboratory for analysis. All sediment samples were air dried, passed through a $75 \mu \mathrm{m}$ sieve to obtain the silt/clay fraction, frozen, and stored in sealed plastic bags. The analysis of the fraction $<75 \mu \mathrm{m}$ was performed since silt and clay size particles adsorb the highest concentrations of pollutants and are more readily transported in suspension in natural waters [9].

\section{Physicochemical characteristics of Lake Chapala sediments}

a) Sediment $\mathrm{pH}$. Approximately $10 \mathrm{~g}$ of air-dried sediment was suspended in $50 \mathrm{~mL}$ of deionized water and manually agitated for $5 \mathrm{~min}$. The suspension was allowed to rest for about $1 \mathrm{~h}$ with occasional shaking until the $\mathrm{pH}$ was measured. b) Organic matter and carbonate content. The determination of organic matter $\left(\right.$ at $\left.550^{\circ} \mathrm{C}\right)$ and carbonate content $\left(\right.$ at $950^{\circ} \mathrm{C}$ ) in sediments were performed by the method of loss on ignition,

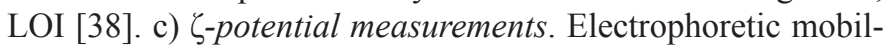
ity of sediments was measured with a Zeta Plus $\zeta$-potential analyzer (Brookhaven Instruments, Holtsville, NY) and converted to $\zeta$-potential.

\section{Sediment total metal digestion}

About $0.5 \mathrm{~g}$ of sediment was digested with $2 \mathrm{~mL}$ of conc. $\mathrm{HClO}_{4}$ and $10 \mathrm{~mL}$ of conc. $\mathrm{HF}$ in a Pt crucible and boiled to near dryness. Then $1 \mathrm{~mL}$ of conc. $\mathrm{HClO}_{4}$ was added and the sample was boiled until white fumes appeared. The residue was dissolved with conc. $\mathrm{HCl}$, transferred to a $50 \mathrm{~mL}$ volumetric flask and brought to the mark. Digestion extracts were used to analyze total metal concentrations by AAS. Blanks containing all the components except sediment were analyzed to determine background interferences. Humidity was determined by weight difference after heating the samples overnight at $105^{\circ} \mathrm{C}$. All measurements were performed in triplicate and average values reported.

\section{Sediment metal fractionation}

The sequential extraction procedure proposed by Tessier et al. [6] was applied to obtain partitioning of trace metals on the lake's sediment samples. Pitfalls of such procedures have been recognized on metal speciation, in particular in anoxic sediments. These include for example, the following: 1) the hydroxylamine solution that acts as moderately reducing reagent in oxic sediments may dissolve amorphous sulfides; 2) chemical fractionation may be modified since transfer from one geochemical group to another may occur during drying. Because of this, Forstner et al. [39] and Ambatsian et al. [40] recommended to apply the fractionation scheme to fresh samples and refer to the water contents for evaluating the amount in dry sediment. However, the surface sediments in Lake Chapala are not anoxic or at least just postoxic; therefore, only slight modifications would be expected during drying. As the procedure of Tessier et al. has frequently been used, easy comparisons can be made with results from studies of other areas [10, 41-42]. The following extractions were obtained: a) Exchangeable: about $1 \mathrm{~g}$ of sediment sample was treated with $10 \mathrm{~mL}$ of $1.0 \mathrm{M} \mathrm{MgCl}_{2}(\mathrm{pH} 7)$ for $1 \mathrm{~h}$ at room temperature with continuous agitation; during this first step, recently formed hydrous oxides may be dissolved [39]; b) Bound to carbonates: the residue obtained from the previous step was treated with $10 \mathrm{~mL}$ of $1.0 \mathrm{M}$ sodium acetate previously adjusted to $\mathrm{pH} 5$ with acetic acid. The sample was continuously agitated for $5 \mathrm{~h}$ at room temperature. Metals weakly bound to oxides or hydroxides can be leached by the acetic solution; c) $\mathrm{Fe} / \mathrm{Mn}$ represent the easily reducible fraction, i.e., $\mathrm{Mn}$ oxides and Fe hydroxides: the residue from the previous step was placed under a reflux of $20 \mathrm{~mL}$ of $0.04 \mathrm{M} \mathrm{NH}_{2} \mathrm{OH}$ : $\mathrm{HCl}$ in $25 \% \mathrm{v} / \mathrm{v}$ acetic acid at $100^{\circ} \mathrm{C}$ for $6 \mathrm{~h}$; d) Bound to organic matter: to the residue from the previous step, $3 \mathrm{~mL}$ of $0.02 \mathrm{M} \mathrm{HNO}_{3}$ and $5 \mathrm{~mL}$ of $30 \% \mathrm{H}_{2} \mathrm{O}_{2}$ were added and the $\mathrm{pH}$ was adjusted to 2 with $\mathrm{HNO}_{3}$; a second aliquot of $3 \mathrm{~mL}$ of $30 \% \mathrm{H}_{2} \mathrm{O}_{2}$ ( $\mathrm{pH} 2$ with $\mathrm{HNO}_{3}$ ) was added and the sample was refluxed again for $3 \mathrm{~h}$. The sample was allowed to cool down to room temperature and $5 \mathrm{~mL}$ of $3.2 \mathrm{M} \mathrm{CH}_{3} \mathrm{COONH}_{4}$ in $20 \%$ $\mathrm{v} / \mathrm{v} \mathrm{HNO}_{3}$ was added. The suspension was diluted to $100 \mathrm{~mL}$ and continuously agitated for $30 \mathrm{~min}$. The addition of ammonium acetate is intended to prevent adsorption of the extracted metals onto the oxidized sediment; e) Residual metals: the residue from the previous step was treated following the total metal digestion procedure described above. All the selective extractions were conducted in centrifuge tubes (polypropylene, $25 \mathrm{~mL}$ ) to minimize loss of solid material. Suspension separation was performed between each successive extraction by centrifuging at $5000 \mathrm{rpm}$ for $30 \mathrm{~min}$. The supernatant was removed with a pipette, the solid residue washed with deionized water, and the washings were saved for further metal analysis to verify mass balances. Comparison of metal content between the two procedures (i.e., total and sequential) showed $\mathrm{a} \leq 10 \%$ difference for most of the metals. All measurements (total and sequential) were performed in triplicate and average values reported.

\section{Acknowledgements}

We are thankful to Universidad de Guadalajara for financial support. We acknowledge Mary Medina (Universidad de Guadalajara) for her assistance in the measurement of water quality parameters, Antonio Reyes-Aguilera (Universidad de Guanajuato) for his assistance with atomic absorption measurements, Marco A. Hernández and Carlos Estrada (Universidad de Guadalajara) for their assistance with map designs. 


\section{References}

1. Garrett, R. G. Hum. Ecol. Risk Assess. 2000, 6, 945-963.

2. Forstner, U.; Wittman, G.T.W., in: Metal Pollution in the Aquatic Environment. Springer, Berlin, 1981.

3. Salomons, W.; Forstner, U., in: Metals in the hydrocycle. Springer, Berlin, 1984.

4. Calmano, W.; Hong, J.; Forstner, U. Water Sci. Technol. 1993, 28, 223-235.

5. Singh, K. P.; Mohan, D.; Singh, V. K., Malik, K. J. Hydrol. 2005, 312, 14-27.

6. Tessier, A.; Campbell, P. G. C.; Bisson, M. Anal. Chem. 1979, 51, 844-851.

7. Franco, D. R.; Berquo, T. S.; Imbernon, R. A. L.; Partiti, C. S. M.; Enzwieler, J. Environ. Geol. 2007, 52, 831-842.

8. Jain, C. K. Water Res. 2004, 38, 569-78.

9. Fytianos, K.; Lourantou, A. Environ. Int. 2004, 34, 11-17.

10. Dollar, N. L.; Souch, C. J.; Filippelli, G. M.; Mastalerz, M. Environ. Sci.Technol. 2001, 35, 3608-3615.

11. Hansen, A. M.; Maya, P. Environ Int. 1997, 23, 553-564.

12. Neuendorf, K. K. E.; Mehl, J. P.; Jackson, J. A. (Eds.), in: Glossary of Geology. American Geological Institute, 5th ed. Fairfax, VA, USA, 2005.

13. WHO (World Health Organization). Guidelines for drinking water quality, v. 1, Recommendations, 2nd ed. Geneva, 1993.

14. USEPA. Nutrient Criteria Technical Guidance Manual: Lakes and Reservoirs. EPA 822-D-99-001, 1999.

15. De Anda, J.; Shear, H., in: The Lerma-Chapala Watershed: Evaluation and Management. Hansen AM and van Afferden M (Eds), Kluwer Academic/Plenum Publishers, NY, 183-198 (Ch 8), 2001.

16. Simons, T.J.Centro de Estudios Limnologicos, Secretaria de Recursos Hidraulicos, Guadalajara, Jal. México. Pan American Health Organization. Project MEX-CWS-010, 1984.

17. Diario Oficial de la Federacion. NOM-127-SSA1-1994. Norma Oficial Mexicana. Environmental health. Water to be used for human consumption. Allowable limits of quality and treatment to make water drinkable [in Spanish]. Mexico, 1994.

18. Hansen, A. M.; Leon-Zavala, A.; Bravo-Inclan, L. Hydr. Eng. Mex. 1995, X, 55-69.

19. Hansen, A. M. Hydr. Eng. Mex. 1992, VII, 92-98.

20. Zárate-del Valle, P. F.; Michaud, F.; Parron, C.; Solana-Espinoza, G.; Israde-Alcantra, I.; Ramirez-Sanchez, H. U.; Fernex, F. in: The Lerma-Chapala Watershed: Evaluation and Management. Hansen AM and van Afferden M (Eds), Kluwer Academic/ Plenum Publishers, NY, (Ch 2), 2001.

21. Schwartzen-Allen, S. L.; Matijevic, E. Chem. Rev. 1974, 74, 385-400.

22. Neihof, R. A.; Loeb, G. I. Limnol. Oceanogr. 1972, 17, 7-16.

23. Hunter, K. A.; Liss, P. S. Limnol. Oceanogr. 1982, 27, 322-335.
24. Beckett, R.; Le, N. P. Colloids Surf. 1990, 44, 35-49.

25. Krauskopf, K. B., in: Introduction to Geochemistry. McGraw Hill, NY, 1967.

26. Hansen, A. M., van Afferden, M., in: The Lerma-Chapala Watershed: Evaluation and Management. Hansen AM and van Afferden M (Eds), Kluwer Academic/PlenumPublishers, NY, (Ch 4), 2001.

27. Persaud, D.; Jaagumagi, R.; Haytion, A. Guidelines for the Protection and Management of Aquatic Sediment Quality in Ontario. Ontario Ministry of Environment and Energy Report, 1993, pp. 30.

28. Salomons, W.; Forstner, U. Environ Technol Lett. 1980, 1, 506517.

29. Perin, G.; Craboledda, L.; Luchese, M.; Cirillo, R.; Dotta, L.; Zanette, M. L.; Orio, A. A.; Lekkas T. D. (Ed), in: Heavy metal in the environment. 1985, 2, 454-456.

30. Ramírez-Sánchez, H. U., Hydrologic and Sedimentologic Characterization of a Tropical lake: Lake Chapala (Mexico). PhD Thesis, Universite de Nice, Sophia Antipolis, France, 2001.

31. Fernex, F.; Zárate-del Valle, P. F.; Ramírez-Sánchez, H. U.; Michaud, F.; Parron, C.; Dalmasso, J.; Barci-Funel, G.; GuzmanArroyo, M. Chem. Geol. 2001, 177, 213-228.

32. Filonov, A. E. Hydrobiologia 2002, 467, 141-157.

33. Limon, J. G.; Lind, O. T.; Vodopich, D. S.; Doyle, R.; Trotter, B. G. Arch. Hydrobiol. 1989, 83, 57-81.

34. Scott, C. A.; Silva-Ochoa, P.; Florencio-Cruz, V.; Wester, P., in: The Lerma-Chapala Watershed: Evaluation and Management. Hansen AM and van Afferden M (Eds), Kluwer Academic/ Plenum Publishers, NY, (Ch 13), 2001.

35. Diario Oficial de la Federacion. NOM 001-SEMARNAT-1996. Norma Oficial Mexicana. Sets the maximum contaminant limits in wastewater discharges to national water bodies, Mexico, 1996.

36. Clesceri, L. S.; Greenber, A. E.; Eaton, A. D. (Eds), in: Standard Methods for the Examination of Water and Wastewater, 20th Edition. APHA, AWWA, WEF. Baltimore, Md. USA, 1999.

37. Alatorre-Zamora, M. A.; Maciel Flores, R.; Rosas Elguera, J. Chapala Upper Crust Inferred by Magnetic Profiles Modeling, Geos 27-3, Union Geofísica Mexicana. Mexico City, 2007.

38. Dean, W. E. Jr. J. Sed. Petrol. 1974, 44, 242-248.

39. Förstner, U.; Ahlf, W.; Calmano, W.; Kersten, M.; Salomons, W.; Sly, P.G. (Ed.), in: Sediments and Water Interactions (3rd Intern. Symp. Interactions between Sedim. and Water Geneva), SpringerVerlag, New York - Berlin, 1986, 371-380.

40. Ambatsian, P.; Fernex, F.; Bernat, M.; Parrron, C.; Lecolle, J. J. Geochem. Explor. 1997, 59, 59-74.

41. O’Day, P. A.; Carroll, S. A.; Randall, S.; Martinelli, R. E.; Anderson, S. L.; Jelinski, J.; Knezovich, J. P. Environ. Sci. Technol. 2000, 34, 3665-3673.

42. Bostick, B. C.; Hansel, C. M.; La Force, M. J.; Fendorf, S. Environ. Sci. Technol. 2001, 35, 3823-3829. 